\title{
Revisiting Domestic Violence in Poe's "The Black Cat": The Narrator Between Psychological Struggle and Egoistic Masculinity
}

\author{
Abdullah K. Shehabat \\ Department of English Language and Literature, Tafila Technical University, Jordan \\ Baker Bany Khair \\ Department of English Language and Literature, Hashemite University, Jordan \\ Zaydun Al-Shara \\ School of Foreign Languages, University of Jordan, Jordan
}

\begin{abstract}
The present paper aims at demonstrating Poe's depiction of domestic violence as a technique to demonstrate his chaotic loss in between his Psychological Struggle and his Egoistic Masculinity. It shows how readers sometimes get lost in search of a judicious cause for the extensive use of violence amongst the chaotic sociopolitical conditions that prevailed that period then. A psychoanalytical perspective was provided to unveil some of the hidden and unsaid facts within some of the gothic literary scenes that were analyzed and examined in light of the narrator's internal struggle between his traumatic psychology and egoistic masculinity. Among others, the present researchers have found that there are intrinsic and extrinsic factors that genuinely contributed to the increasing scenes of persistent violence committed by the unnamed narrator, but not limited for alcoholism and the unbalanced psychological disorder as the narrator wished to display.
\end{abstract}

Index Terms - gothic literature, domestic violence, Poe, unnamed narrator, egoistic masculinity

\section{INTRODUCTION}

Despite the hypothetical development of modern civilization in fostering kindness and love, human rights, and egalitarianism among races and genders, these crimes of life-threatening violence against humans and/or animals continue to emerge and instead of being lessened, they appear to be increasing in their prevalence. Reading Edgar Alan Poe's "The Black Cat" can never leave readers stop thinking about the tremendous size of physical (domestic) violence employed by him, intently targeting a woman as well as a cat. Readers would like to definitely keep questioning the gloomy nature of this literary piece, which deleteriously hurts the intricate feelings of human beings due to the excessive exercise of torture practiced against human beings and animals alike. To be considered as a gothic literary genre, Patrick Kennedy (2020) believes that it must revolve around a large, ancient house that conceals a terrible secret or serves as the refuge of an especially frightening and threatening character (p. 5).

"The Black Cat" was first published in the United States' Saturday Post in August 1843 (Piacentino, 1998, p. 153). Having become immediately popular, Poe considers it one of his best tales. Though, he sometimes views it as one of his most horrifying and mystifying works, "For the wildest, yet homeliest narrative which I am about to pen ..." (Poe, 2013, p. 34). Poe further adds "Tomorrow I die. Tomorrow I die, and today I want to tell the world what happened and thus perhaps free my soul from the horrible weight which lies upon it" (p. 34). Assumingly, the narrator has written those words while he is in jail and is about to be put to death the next day, thus reflecting on the psychological and mental changes that have dominated his personality during the story.

\section{THE POET AND THE GOTHIC WORK}

Although this type of work unequivocally handles a topic that seriously has all kinds of emotional harm on society, writing this paper has come as an attempt to highlight the significance of preventing all patterns and practices of violence on people and animals, as well. These include "domestic"/offline/fleshy abuse, as well as physical/nonphysical violence, such as representational, psychological, coercive control, as well as attending to their overlaps, intersections and combinations" (Flury, Nyberg, and Riecher-Rössler, 2010, p. 1). As a matter of fact, it is approved that women with a percent of 10-35\% have been victims to this gender-related violence sometime in their lives (Ibid, p. 2). Further, we attempt to explore the nature and limits of violence by way of psychologically analyzing the domestic and/or physical related scenes as presented by the American author, Edgar Alan Poe.

Edgar Allan Poe, whose works have critically contributed to the world genre of gothic literature that have influenced the American Romantic Movement as well as the science fiction literary genre, was born in a humble lodging house 
near Carver Street on January 19, 1908. Unfortunately, his birth has evoked a pecuniary and emotive turmoil in the Poe's family ${ }^{1}$ (Meyers, 2013, p. 4). He was the first well-known American writer to try to earn a living through writing alone, resulting in a financially challenging life and career that has plagued his life with copious fear accompanied with violent actions in life. In fact, the life standards which Poe lived proves that he, as Diamond (2006) proposes, has never identified with his parents because he never saw them, a feature, we argue, that have played on the matter of his masculine gender identity. He has developed an egoistic masculine style throughout his life which resulted from the "dis-identification" from his parents. Definitely, if he, whom he dramatizes himself under the cover of the unnamed narrator, had had a healthy masculine gender identity, he would not have suffered both socially and psychologically, as clearly presented in his masterpiece, "The Black Cat" (Diamond, 2006, p.1100).

"The Black Cat" belongs to the literary genre of Gothic Literature which, for many critics, is difficult to define and is viewed as unstable (cf. Rata 2014, Botting 2012, Hogle 2002). Kennedy (2020) perceives it as the art of writing that employs dark and picturesque scenery, startling and melodramatic narrative devices, and an overall atmosphere of exoticism, mystery, fear, and dread. However, Rata (2014) views it from a macro sociopolitical prospective. She reads it as a quite revolutionary [literature] that aesthetically and politically questions [...] the systems of authority, the social order and existing social problems (p. 104). "The Black Cat" also bears neat similarities with the story of the "The TellTale Heart" where the anonymous narrator has been arrested for murder and "who persists that he cannot be insane before he begins an account of a murder that he committed". In "The Black Cat," we are bombarded with a man who is aware of the psychological and emotional transformations that have dragged him to become a murderer in spite of the state of the psychological disturbance that hit him most of the time. While the protagonist of "The Tell-Tale Heart" explains his case for "butchery" as if his reason were apparent and unavoidable, the narrator of "The Black Cat" is on some level aware of his irrationality, even though he chooses to ignore it and surrender to the baser humanoid emotions of unreasonableness and hatred (qtd. in Al-hmdni, 2020, p.3969).

Definitely, whether viewed from a macro level or a micro one, readers of Edgar Alan Poe's 'The Black Cat' would normally observe all elements of picturesque scenery, exoticism, horror, melodrama, social order as well as social problems. Furthermore, as Lombardi (2020) infers the "The Black Cat" demonstrates numerous elements of the supernatural, mystery, madness, high emotions, death, the evil side of human nature, violence, and more other elements, which situate this short story in the gothic genre (n.p). As far as this paper is concerned, we found that there are two foremost factors that played an inordinate role in turning this tale into a gothic work: the excessive emotions and the embodiment of the supernatural world. The former is very clear in many scenes. At the beginning of the story, readers feel the excessive amount of mutual love and feelings between the narrator, his wife and the pets, especially the loving relationship with his cat "I named the cat Pluto, and it was the pet I liked best, I alone fed it, and it followed me all around the house. It was even with difficulty that I stopped it from following me through the streets" (Poe, 2013, pp.345). However, with the passage of time, the narrator has radically changed his stance of emotional support towards Pluto and therefore begins to treat it badly; he becomes an obsessed man passionate about getting rid of the cat that haunts him (Wall, 2020, p. 2). He explains how this change has happened overnight, "As I entered I saw-or thought I saw - that Pluto, the cat, was trying to stay out of my way, to avoid me. This action, by an animal which I had thought still loved me, made me angry beyond reason. My soul seemed to fly from my body. I took a small knife out of my coat and opened it" (Poe, p. 35).

The latter, on the other hand, is the supernatural world represented by the weird belief that all the black cats are undercover witches, “...which regarded all black cats as witches in disguise" (Wall, 2020, p.4). The evil side of the human nature and the presence of madness is another element that talks about the supernatural gothic world. At the beginning of the story, the narrator confirms that he is a sane person, "Yet mad I am not..." (Poe, 2013, p.35). This quote explains the sudden shift in his personality from animal lover to a murderer. Further, the setting of the "The Black Cat" in a basement with dark and gloomy atmosphere, similar to a castle with a dungeon, further gives the work more gothic features.

To evade getting scattered here and there in the shades of different types of violence (emotional, spiritual, psychological violence, cultural ...etc.) the current paper largely scrutinizes the theme of domestic violence as pertaining to creatures, especially cats and women. To do so, a close analytical reading of domestic-related violence will be identified, commented on and examined in light of the appropriate psychological background of Poe's story.

\section{DOMESTIC VIOLENCE: DEFINITIONS AND REASONS}

We here define violence as enforcement actions practiced against defenseless creatures using available equipment to enforce humiliating and influential results on targeted objects, thus affecting their physicality and psychology. The victimized objects, in such case, would not object and/or report their complaints due to different criteria, mainly gender, color, race, religion, ethnicity and authority. The most widely accepted definition of violence, sometimes termed "intentional interpersonal injury", is, with relevance to the current study, the behavior by persons against persons that

\footnotetext{
${ }^{1}$ The way Edgar's father David Poe had faced many difficult and embarrassing situations when requesting his cousin George Poe for money with unbalanced tones and humiliating manner, thus reflecting negatively on the psychological structure of Edgar, thus directing him to a way through which he gains money: writing.
} 
intentionally threatens, attempts, or actually inflicts physical harm" (Reiss and Roth, 1993, p. 6). To further pinpoint, we support Green's perspective regarding the terminologies "aggression" and "antisocial behavior" he perceives of as lesser forms of violence (2018, p.183). The current paper aims not only to identify the rationale behind each violent practices, but also to highlight the significance of the circumstances that drove the unnamed narrator, the victimizer, to practice different forms of violence against the victimized and eventually to judge him in light of his deeds: to blame or not.

By and large, there are many major factors for committing violent acts. The most agreed upon factor is the lack of religious faith. Some studies also consider violence as a result of traditional societal heritage; such as inequality between boys and girls, poor upbringing, and growing up in a violent environment. While other studies have pointed out to the absence of dialogue between the members of the society and/or the family, the vast majority of the other studies attribute violence to economic factors. Still, one remains confused when trying to identify the most relevant factors for committing murderous actions, "as the motivational dynamics and purpose for the crime are internalized in the offender's own mind and are therefore not necessarily discernible from the evident situational factors of the crime" (Kocsis, 2008, p. X).

\section{THEORETICAL BACKGROUND}

Much scholarship has been written about the theme of violence, particularly domestic violence. Nevertheless, very few works have precisely tackled it in a case study where violence is practiced because an animal was being very kind to its owner. That is, violence is practiced for no reasonable cause, or to be more precise, for no reason. In their paper titled "Domestic Violence against women: definitions, epidemiology, Risk factors and consequences" Marianne Flury, Elisabeth Nyberg, and Anita Riecher-Rössler (2010) pointed out to the major risk factors of domestic violence e.g., young age, being unmarried, lower education, violence practiced during childhood and addiction to drugs and alcohol. Additionally, they found that there was a strong correlation between physical violence and emotional violence (1). They pointed out how, in a WHO study, 10 different countries where women were subject to violence have resulted with horrifying extent of violence practiced against them by their intimate partners, especially from a psychological domain.

In another cause-effect study titled, 'In search of the cause of violence in Edgar Allan Poe's The Black Cat, Alhmdni (2020) sheds light on the obscuring characterization and the prevailing inconsistency and absurdity in Edgar Allen Poe's short story, "The Black Cat". Using Lacan's psychoanalysis approach and Zizek's analysis of the concept of violence, he argues that the sociological side has had a major influence on the protagonist's character (p. 33). Further, Al-shiban's study entitled "Animal Cruelty and Intimate Partner Homicide in Edgar Allan Poe's 'The Black Cat' (2019)" further elaborates on the notion of the psychological violence practiced against animals and humans alike. To do so, AlShiban employs an analytical approach to question the relationship between the brutality practiced against animals e.g., Pluto, the Cat, and that practiced against humans, the narrator's wife. In his conclusion, Al-shiban proves that Poe's narrator was engrossed by power and authority which result in transforming his violent acts towards animals and human beings, alike, into sadistic exercise of authority and control over others.

Drawing upon a related theme, Bliss (2009) attributes the household horror in "The Black Cat" to the loss of the apparent feminine traits of the unnamed narrator within his huge sensitive masculine world. Below Bliss details how the narrator's feminine traits have disappeared in the melting pot of the dominant world of masculinity. He states that

The male narrator's feminine traits are apparent and he struggles to recast this inappropriate femininity into a sensitive masculinity. He attempts to actively maintain a benign persona that masks his femininity; however, he performs a kind of hypermasculinity that manifests itself in increasingly horrific acts of violence (p. 96).

As long as the above quote is concerned, it is apparent that most views revolve around the narrator's masculine mentality that controlled his behaviors, making him a choiceless figure, incapable of striking balance between his emotional instincts with that of his egoistic masculinity. A long with the masculine world of the narrator, other critics have attributed the violence practiced by Poe's unnamed narrator to no one but to the surrounding environment that created such psychopathic, remorseless and pitiless personality. Hester and Segir (2014) lay blame on the type of the narrator, a textbook psychopathic personality, created by Poe. For them, the narrator not only lacks remorse and empathy but he also lacks a human conscience that steers people's lives. Creating an impulsive, egocentric personality to deceive those around him makes him, according to public defenders, unaccountable for his crime (p. 180).

\section{Method, Discussion \& ANALYSiS}

The present paper aims at demonstrating Poe's depiction of domestic violence as a technique to demonstrate his chaotic loss in between his psychological struggle and his egoistic masculinity. It shows how readers sometimes get lost in search of a judicious cause for the extensive use of violence amongst the chaotic sociopolitical conditions that prevailed then. A psychoanalytical perspective was provided to unveil some of the hidden and unsaid facts within some of the gothic literary scenes that were analyzed and examined in light of the narrator's internal struggle between his traumatic psychology and egoistic masculinity. Since this paper focuses on the notion of domestic violence in "The Black Cat," the reader should be able to realize the style employed by the unnamed narrator and consequently understand the hidden elements of the gothic scenes. The theme of violence has been perceived by identifying a parade of violent acts. The unnamed narrator conveys a horrific atmosphere by describing the crimes in precise yet conscious 
state of awareness, providing details of the gothic elements to the scenes. The techniques Poe uses are "polysyndeton" and "asyndeton" ultimately intended to make the utterances of the narrator appear more breathtaking and animated. In addition, he uses fronting and foreshadowing to impart the feeling of the emerging terror (Wall, 2020). Additionally, we found that Poe has varied in his style to dramatize horror in his gothic work.

Using a sequence of techniques has undoubtedly evoked a more intense and dreadful atmosphere, thus laying more blame on the narrator. One could therefore notice how he once plays with the language i.e., the repetition of conjunctions, to express a state of hesitancy mingled with carelessness as in the sentence "[i]t was now the representation of an object that I shudder to name -- and for this, above all, I loathed, and dreaded, and would have rid myself of the monster had I dared..." (Emphasis added, Poe, pp. 38-39). Poe also resorts to asyndeton to dramatize horrible actions, such as "I took from my waistcoat-pocket a pen-knife, opened it, grasped the poor beast by the throat" (Wall, p.2). It should be emphasized that Poe further does not discard the significance of one's emotional state. He mentions that "[o]ne night, returning home, much intoxicated, from one of my haunts about town" (Ibid, p.2) and "I blush, I burn, I shudder..." (Ibid, p.5). Below is the analysis and discussion of some of the major violence scenes.

The following scenes extensively elaborate on the narrator's unsaid utterances in the major scenes that include violent acts. The first scene of violence is practiced against a domestic pet, the cat Pluto, a cat that simply loves its owner, among other pets, that lives with the narrator and his wife. From his language, it can be easily inferred that there is much unuttered discourse that is hidden beyond the margins of each scene. When the narrator cuts Pluto's eye (gouging it out), he states that "I took from my waistcoat pocket a pen-knife, opened it, grasped the poor beast by the throat, and deliberately cut one of its eyes from the socket! "(Poe, 2013, p.39). Here, the irresponsible attitude towards the defenseless domestic animal, Pluto, is clear-cut evidence that the narrator purposefully and consciously has intended an organized crime. Language wise, the resort to the first person speaker in context confirms the conscious intent of murder based on a decisive act. What emphasizes this point is the precise yet extensive use of descriptive phraseology (e.g., waistcoat, a pocket penknife, cutting one of its eyes from the socket...etc.) that re-emphasize his preconceived intent to commit murder. Additionally, the chronology of events underscores the state of physical and psychological consciousness, thus justifying another simultaneous state, the state of feeling remorseless although the narrator claims that he sometimes feels remorseful for his crime by drinking alcohol and by crying. He states, "But my disease grew upon me-for what disease is like Alcohol! — and at length even Pluto, who was now becoming old, and consequently somewhat peevish — even Pluto began to experience the effects of my ill temper" (Poe, 2013, p.40).

Another linguistic evidence that classifies the narrator as an on-purpose-killer is the phrase "cool blood," a verbal utterance that directly accuses the narrator for targeting a defenseless domestic pet. Forgetting all his previous temporary regrets, he recalls the day when he intentionally hangs Pluto, "[o]ne morning, in cool blood, I slipped a noose about its neck and hung it to the limb of a tree" (Poe, 2013, p.42). In fact, the paradoxical idea that mismatches with "cool blood" is when he mentions that "he couldn't stop crying" (ibid). This idea conveys an untarnished message he wants to deliver: he is no longer concerned or even moved by the murder scene whenever he recalls it. At the point when he claims that "coolness didn't continue" (ibid) readers would understand the speaker's hidden intent to empathize with him, a point that is not conceivable due to the conflicting yet ironic scenarios he creates. At this point, it is worth recalling Michael's proposition (2021) that further blame lays on the narrator, "human being has a perverse, wicked side-another self-that can goad him into doing evil things that have no apparent motive" (p. 4).

After Pluto's hanging, the narrator buys a cat that is roughly similar to Pluto yet in weird way; he takes it to his house because he claims that he still loves pets. Nevertheless, he could not forget the previous experience with Pluto and therefore remains staggering in between his unexpected fear, the psycho-emotional fear and the unpredicted future with the cat, because he believes in the supernatural force black cats have. He goes on maltreating the cat for no reason but because it keeps chasing him. Apparently, the narrator always intends to get drunk to the fullest whenever he thinks of committing a violent domestic act indoors, as if he were justifying the scene with being drunk, as in both of the scenes where he points out to his mental state by giving readers the impression that it is only alcohol addiction that drives him into committing such deeds against other creatures and humans. It can be argued that this scene in particular stands against him, accusing him for the state of the lack of awareness where he intently places himself. It is worth mentioning that the accurate procedure of hiding the corpus of his wife was neither simple nor expected.

The second scene of violence, when the narrator blindly uses an axe to kill his wife as she tries to interfere to defend the second victimized cat by holding her husband's hand, is evidence against the narrator. His wife was the second victim. He mentions that "[g]oaded, by the interference, into a rage more than demoniacal, I withdrew my arm from her grasp, and buried the axe in her brain" (Poe, 2013, p.11). As can be inferred from the quote, it is found that the narrator is conflicted between two states of affairs: pre-killing and post-killing. As explained earlier, before he begins the countdown of attack he equips himself with the notion of being drunk, using it as a pretext for killing. However, after he administers his crime he begins laying blame on other factors, e.g. extrinsic interference, rage and demonic forces. Ostensibly, he must have thought of those reasons as means to justify his obsession with domestic violent deeds and also to let readers delve into the psycho-emotional state that drags him into killing.

Al-Shiban (2019) explains some readings of the post-killing scene where the narrator feels fully-aware of the murder cases he commits yet without hiding his state of carelessness. "There is no sense of guilt or remorse. He is not horrified afterwards. Instead, he boasts that he slept peacefully that night, "I soundly and tranquilly slept; aye, slept even with the 
burden of murder upon my soul!" (2019, p. 36). Apparently, at the beginning the narrator succeeds in misguiding the readers by explicitly referring to alcoholism, "a repetitive but inconsistent and sometimes unpredictable loss of control of drinking which produces symptoms of serious dysfunction and disability, frequently including a physical addiction" (ibid). During the story, Poe mentions drinking many times considering it a problem. "But my disease grew upon mefor what disease is like Alcohol!" (Poe, p. 38). Also, there are some other reasons like resistance to tenderness, perverseness, and the demon. However, later he confesses that he was not under any pressure to make him kill. He was therefore remorseless and guiltless.

Now, we move to the notion of negligence' in this story, which is an interesting theme. Seemingly, negligence is originated, by and large, from imagination rather than perception. The appearance of this theme is when the narrator starts to neglect his pets and his wife; he no longer cares about them. Not only that, but he also mistreats them and ignores their existence." I not only neglected, but ill-used them"(Poe, 1843, p.2). He thinks that they do the same thing toward him. Here, it appears that he starts to hallucinate and imagine things that are not true, a notion that Thomas (2014), among others like McGinn (1999), view it as a conceptually incoherent notion' or a 'psychologically trivial'. We argue here that the narrator wasn't under the influence of perception, but he was under the influence of imagination. That is the reason beyond Pluto's torture and later killing; he thinks that Pluto ignores him. "One night, returning home, much intoxicated, from one of my haunts about town, I fancied that the cat avoided my presence" (Emphasis added, Poe, 2013, p.37). Here, we dare say that negligence, or what Poe terms as fantasy, is a very harmful violence reason that leads the narrator to act vehemently.

Despite the multiple covers that the narrator uses to make himself irresponsible due to a set of fanciful acts, hallucinations, imaginations and misunderstanding situations, readers can deduce the extreme yet the unimaginable high level of organized thinking and secrecy that reflect the narrator's egoistic masculinity. Nonetheless, those successful tactics are not enough to unveil his inner-hidden-patterns of thought. He attentively and consciously describes the way he hides the corpus of his wife:

The walls were not very strongly built, and I found I could easily take down those stones. Behind them there was, as I knew there must be, a hole just big enough to hold the body. With much effort I put the body in and carefully put the stones back in their place. I was pleased to see that it was quite impossible for anyone to know that a single stone had been moved (Poe, p. 37).

In short, the quote above sums up almost all kinds of psychological, physical, and intellectual powers that enabled the narrator to successfully hide his wife's body. He infers that there was a hole within the wall that would be wide enough to fit his wife's dead body, which means he was psychologically aware rather than psychologically unbalanced. Also, when he mentions that he exerts much effort to place the body in that hole, he seemingly uses his physical strength and stamina, thus hinting at another kind of power i.e., physical power. Eventually, he explains how he was happy and confident when he infers that no one would be able to recognize the rebuilt stones, which also reflects on his high intellects.

\section{CONCLUSION}

To conclude, although a number of studies have exempted the narrator from responsibility of his violent acts committed against his wife and his pets claiming that they he was under the influence of some extrinsic factors like alcoholism, the sensitive political milieu, the dysfunctional life and lack of faith, this study proves a different argument. In fact, the interplay of the early masculine gender identity development and the later life challenges that confronted Poe, clearly dramatized by his unnamed narrator, have led him to an ambiguous yet risky mature masculine identity, a notion Diamond (2006) has stressed as a major threat that force humans to make irresponsible life decisions (pp.11001102). Such maturity is the evidence that the narrator was having joy and willingly committing violent acts. The present study therefore proves that the narrator who was intentionally unnamed was decisive to commit his violent acts, a technique Edgar Alan Poe also employs to make the gothic story more suspenseful yet more ambiguous in addition to not display much more of his early gender identity. He fabricates a number of unconvincing reasons, most extrinsic and have nothing to do with his egoistic masculinity development stages throughout his life, to refer to the state of subconsciousness when he practiced violence against his wife and his domestic pets, the cats.

Having both linguistically and psychologically analyzed a number of his quotes, especially those in the post-killingscenes, we found that he tries to act as if he were mentally disabled by always appearing in a state of lacking awareness, a major state he clearly demonstrates all over the story. Furthermore, providing some pretexts that place him in the corner of the oppressed and marginalized and/or what Poe terms as "negligence" (p. 37), e.g., when he claims that the cat was ignoring him, is another evidence that he does not suffer any psychological or mental problems but he is aware of the realistic situation that encompasses him. This definitely is a sequence of his egoistic mentality that is primarily responsible for all the violent acts practiced against his domestic people.

\section{REFERENCES}

[1] Al-hmdni, T. (2020). "In Search of the Cause of Violence in Edgar Allan Poe's 'The Black Cat". International Journal of Psychosocial Rehabilitation. 24 (10).33-47. 
[2] Al-Shiban, Afra. (2019). Animal Cruelty and Intimate Partner Homicide in Edgar Allan Poe's "The Black Cat". Retrieved January $\quad 23^{\text {rd }}, \quad 2020 \quad$ from https://www.researchgate.net/publication/338695292_Animal_Cruelty_and_Intimate_Partner_Homicide_in_Edgar_Allan_Poe' s_The_Black_Cat

[3] Ann V. Bliss. (2009). Household Horror: Domestic Masculinity in Poe's The Black Cat, The Explicator, 67:2, pp. 96-99.

[4] Diamond, J. M. (2006). Masculinity Unraveled: The Roots of Male Gender Identity and the Shifting of Male Ego Ideals Throughout Life. Journal of the American Psychoanalytic Association 54(4):1099-130.

[5] Flury, M, Nyberg, E, \& Riecher-Rössler, A. (2010). "Domestic Violence against women: definitions, epidemiology, Risk factors and consequences". The European Journal of Medical Sciences. 140 (w)1309-36.

[6] Greene, Michael B. (2021). "Violence." Encyclopedia of Public Health. Retrieved April 08, 2021 from Encyclopedia.com. Retrieved January $27^{\text {th }}$ ， 2020 from: https://www.encyclopedia.com/education/encyclopedias-almanacs-transcripts-andmaps/violence.

[7] Hester, V., \& Segir, E. (2014). Edgar Allan Poe: "The Black Cat," and Current Forensic Psychology. The Edgar Allan Poe Review, $15(2), 175-193$.

[8] Kennedy, P. (2021). Gothic Literature. Thoughtco. Retrieved January 23 ${ }^{\text {rd }}$, 2020 from https://www.thoughtco.com/gothicliterature2207825

[9] Kocsis, N. Richard, ed. (2008). Serial Murder and the Psychology of Violent Crimes. New Jersey: Humana Press.

[10] Lombardi, E. (2020). "The Black Cat" Study Guide. Retrieved April 08, 2021 from https://www.thoughtco.com/the-black-catthemes-and-symbols-738847.

[11] Meyers, J. (1992). Edgar Allan Poe: His life and legacy. New York: Charles Scribner's Sons.

[12] Piacentino, E. (1998). Poe's "The Black Cat" as psychobiography: some reflections on the narratological dynamics. Studies in Short Fiction, 35(2), p. 153-167.

[13] Poe, E. A. (2013) Edgar Alan Poe Storyteller: Seven Stories. [Washington, D.C.]: Office of English Language Programs, Bureau of Educational and Cultural Affairs, U.S. Department of State.

[14] Rata, I. (2014). An Overview of Gothic Fiction. Translation Studies: Retrospective and Prospective Views. 7 (17). Pp 104-114.

[15] Reiss, A. J., and Roth, J. A., eds. (1993). Understanding and Preventing Violence. Washington, DC: National Academy Press.

[16] Thomas, J. and Nigel, T. (2014). The Multidimensional Spectrum of Imagination: Images, Dreams, Hallucinations, and Active imaginative perception. Humanities. 3 (1): 132-184.

[17] Wall, Raphael. (2020). "Stylistic Devices: An Analysis of "The Black Cat" by Edgar Allan” Munich, GRIN Verlag. Retrieved January $22^{\text {nd }}, 2020$ from https://www.grin.com/document/901460.

Abdullah K. Shehabat, an associate professor of American Literature and Translation studies at Tafila Technical University. He has been teaching at different universities in Jordan and abroad. As part of his sabbatical leave expertise in Bahrain, he taught courses in Arabic language for non-native speakers. His major areas of research interest include American literature, postcolonial literature, African American literature and Translation studies. He published a number of referred papers in internationally recognized journals.

Baker Bany Khair is currently an associate professor of English literature at the Hashemite University, Jordan. He has published several articles on different aspects and topics that mainly deal with American and British Literature, cultural studies, and Film. His research interests are varied and multifarious, but he especially focuses on the 19TH Century American novel and poetry, 1960s and 1950s American films, Gothic Literature, culture, and history

Zaydun A. Al-Shara is an Assistant Professor of Literary Criticism at the University of Jordan. His research interest is in literary criticism, narratology, and American literature. 